\title{
Genetic Variations in Albumin and Transferrin as Species Markers in Plasma of Callithricidae
}

\author{
Tatsuro Shimaoka**, Atsushi Nagai, Shu Chuan Lee, Miho Takeshi, \\ Shozo Suzuki and Shigenori Ikemoto*
}

\begin{abstract}
Institute of Animal Serology, Tokyo University of Agriculture, 1-1-1, Sakuragaoka, Setagaya-ku, Tokyo 156, Japan, and *Nodai Research Institute, 1-1-1, Sakuragaoka, Setagaya-ku, Tokyo 156
\end{abstract}

(Received 10 November 1982 / Accepted 23 August 1983)

\begin{abstract}
Albumin (Alb) and transferrin ( $\mathrm{Tf}$ ) polymorphism in plasma of Callithricidae was investigated by means of starch gel electrophoresis. In 52 blood samples of three species (Saguinus mystax, S. oedipus and S. labiatus), four Alb phenotypes (Alb 1, Alb 2, Alb 3 and Alb 2-3) and two Tf phenotypes (Tf 1 and Tf 2) were observed. No Alb variant was found in S. oedipus and S. mystax.
\end{abstract}

Ecological, morphological and taxonomical studies of Callithricidae have been reported by many authors $[3,7]$.

Recently, taxonomical relationships in this genus were studied by using genetic variations in blood proteins. Those genetic variations were examined by means of gel electrophoresis and immunological technique. Genetic variations in plasma proteins of non-human primates have also been observed and applied to taxonomy; for example, macaques, chimpanzee and others $[4,5,6,9,11,12,13]$.

The taxonomical relationship among species (Saguinus oedipus, Saguinus mystax etc.) of Callithricidae has received a little study by electrophoretic and immunological techniques $[1,2]$. We also have investigated, by means of electrophoresis, the taxonomical relationships among S. mystax, S. oedipus and S. labiatus by using the genetic variations in blood proteins as genetic markers.

This paper describes the distinctive electrophoretic patterns of plasma albumin
(Alb) and transferrin (Tf) in each species. Fifty-two blood samples (10 of $S$. mystax, 16 of $S$. oedipus and 26 of $S$. labiatus from the Tokyo Metropolitan Institute of Medical Science) were cted from collonies at the Institute of Animal Serology, Tokyo University of Agriculture. Starchgel electrophoresis of plasma proteins (Alb, Tf) was performed according to the method of Krishnamurthy et al. (1974).

The electrophoretic patterns of Alb and Tf are shown in Fig. 1. Four phenotypes were observed in Alb (Fig. 1). In S. oedipus, no variant was observed. There was one phenotype, named Alb 1, consisting of the fastest-migrating band. In $S$. mystax, no variant was observed. Only one phenotype, named Alb 3, consisting of the slowest-migrating band, was observed. In $S$. labiatus, three phenotypes were observed and named Alb 2, Alb 3 and Alb 2-3. The most common phenotype was Alb 2-3 which consisted of two bands, Alb 2 and Alb 3 . The rarest phenotype was Alb 2 which consisted of

**Present address : Department of Legal Medicine, Showa University, School of Medicine, 1-5-8, Hatanoshi, Shinagawa-ku, Tokyo, 142, Japan. (昭和大学医学部法医学教室) 


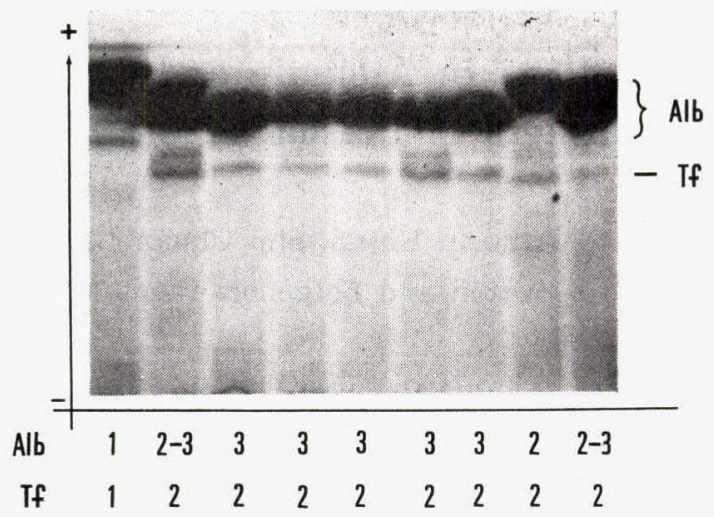

Fig. 1. Starchgel electrophoretic patterns of albumin and transferrin in the sera of the three species of Saguinus

Table 1. Distribuion of plasma albumin (Alb) phenotypes in the three species of Saguinus

\begin{tabular}{ccrccc}
\hline \multirow{2}{*}{ Species } & \multirow{2}{*}{$\begin{array}{c}\text { No. of } \\
\text { samples }\end{array}$} & \multicolumn{4}{c}{ Alb phenotype } \\
\cline { 3 - 6 } & Alb 1 & Alb 2 & Alb 2-3 & Alb 3 \\
\hline Saguinus mystax & 10 & 0 & 0 & 0 & 10 \\
Saguinus oedipus & 16 & 16 & 0 & 0 & 0 \\
Saguinus labiatus & 26 & 0 & 7 & 11 & 8 \\
Total & 52 & 16 & 7 & 11 & 18 \\
\hline
\end{tabular}

Table 2. Observed and expected values of albumin (Alb) phenotypes of Saguinus labiatus

\begin{tabular}{lccccccc}
\hline \multirow{2}{*}{ Species } & \multicolumn{3}{c}{ Alb phenotype } & D. F. & $\chi^{2}$ & P \\
\cline { 2 - 4 } & Alb 2 & Alb 2-3 & Alb 3 & & \\
\hline \multirow{2}{*}{ Saguinus labiatus } & 7 & 11 & 8 & & & \\
& $(6.01)$ & $(12.98)$ & $(7.01)$ & 2.058 & 0.623 & P $>0.05$ \\
\hline
\end{tabular}

Figures in parentheses are expected values.

Table 3. Distribution of plasma transferrin (Tf) phenotypes in the three species of Saguinus

\begin{tabular}{cccc}
\hline \multirow{2}{*}{ Species } & \multirow{2}{*}{$\begin{array}{c}\text { No. of } \\
\text { samples }\end{array}$} & \multicolumn{2}{c}{ Tf Phenotype } \\
\cline { 3 - 4 } & Tf 1 & Tf 2 \\
\hline Saguinus mystax & 10 & 0 & 10 \\
Saguinus oedipus & 16 & 16 & 0 \\
Saguinus labiatus & 26 & 0 & 26 \\
Total & 52 & 16 & 36 \\
\hline
\end{tabular}


one band intermediate between Alb 1 and Alb 3. The third phenotype was Alb 3 which was the same as the one in $S$. mystax. The number of Alb variants found in the present work was highest in S. Iabiatus (Table 1). Genotypes and gene frequencies were estimated by the direct counting method and the assumption of Hardy-Weinberg equilibrium decided by means of Nass's (1959) $\chi^{2}$ test for small samples. The results agree with the hypothesis that Alb polymorphism is controlled by two codominant genes, $A l b^{2}$ and $A l b^{3}$ ( $\mathrm{p}>0.05$ ) (Table 2). Therefore, this Alb variation will be useful for the study of population genetics.

Two Tf phenotypes were observed in this investigation (Fig. 1), but no variant was found. In S. oedipus, however there was one phenotype, named Tf 1 , consisting of a fast-migrating band. In the other two species, a phenotype which consisted of the slow-migrating band was observed and named Tf 2 (Table 3). Electrophoretical patterns of Alb and Tf show that $S$. mystax is taxonomically similar to $S$. labiatus and that both are distinct from S. oedipus.

Cronin and Sarich (1978) postulated that $S$. mystax is appreciably distant from $S$. oedipus in evolutionary units.

However the taxonomical relationship between S. labiatus and S. mystax or S. oedipus remains unknown.

Hershkovitz (1977) reported that genus Saguinus is divided into six groups ( $S$. nigricollis, S. mystax, S. bicolor, S. midas, S. inustus and S.oedipus) in three sections (Hairly, Mottle and Bare-face tamarin) from the morphological point of view.

We postulate that S. mystax and $S$. labiatus have a very similar evolutionary unit of relatively recent origin and support the concept that $S$. labiatus and $S$. mystax belong to the S. mystax group which was postulated from a morphological point of view by Hershkovitz (1977).

We are indebted to Dr. J. Sugi, Chief director of Nodai Research Institute, Professor T. Niwa, Nodai Research Institute, Professors K. Tanaka and Y. Ishijima, Tokyo University of Agriculture, and Professor M. Mayumi, Jichi Medical School for their kind encouragement.

\section{References}

[1] Cronin, J. E., and Sarich V. M. (1975). J. hum. Evol., 4, 357-375.

[2] Cronin, J. E., and Sarich V. M. (1978). Prim. Med., 10, 12-16.

[3] Hershkovitz, P. (1977). The Living New World Monkeys. The University of Chicago press, Chicago.

[4] Ishimoto, G. (1972a). J. Anthrop. Soc. Nippon, 80, 250-274.

[5] Ishimoto, G. (1972 b). J. Anthrop. Soc. Nippon, 80, $337-350$.

[6] Ishimoto, G. (1973). J. Anthrop. Soc. Nippon, 81, $1-13$.

[7] Kleiman, D. G. (1977). The Biology and Conservation of the Callithricidae. Smithsonian Institution Press, Washington.

[8] Krishnamurthy, U. S., Bhuvanakumar, C. K., and Rathnasabapathy, U. (1974). Anim. Blood Grps. Biochem. Genet, 5, 125-127.

[9] Moor-Jankowski, J., and Socha, W. W. (1980). Development., 45, 35-45.

[10] Nass, C. A. G. (1959). Biometrika, 46, 365-386.

[11] Nozawa, K., Shotake, T., Ohkura, Y., and Tanabe, Y. (1977). Japan J. Genet., 52, 12-30.

[12] Shotake, T. (1979). Serum albumin and erythrocyte adenosine deaminase polymorphisms in Asian macaques with special reference to relationships among Macaca assamensis, $M$. radiata and $M$. mulutta.

[13] Socha, W. W., and Moor-Jankowski, J. (1980). Folia Primatol., 33, 172-188. 


\section{Callithricidae における種の標識としての血漿アルブミン \\ およびトランスフェリンの遺伝的変異}

島岡達朗・永井淳・李淑娟・武美穂

鈴木正三・池本卯典*

東京農業大学家畜血清学研究所

*東京農業大学総合研究所

デンプンゲル電気泳動法を用いて, Callithricidaeに おけける血漿アルブミンおよびトランスフェリンの多型現 象の有無について調査した。調查した個体は，S. mystax, S. oedipus 拉よび S. labiatus の 3 種計52例であ り, アルブミンにおいては Alb 1, Alb 2, Alb 3 およ
び Alb 2-3 型の 4 つの 表現型そしてトランスフェリン においては Tf 1 および Tf 2 型の 2 つの表現型を確認 した。また，アルブミンに扎いては S. oedipusおよび S. mystax は, 変異型が確認されなかった。 